\title{
Potential disease-causing organisms associated with mantle cavity of Pacific oyster Crassostrea gigas in northern New Zealand
}

\author{
P. Dinamani
}

Fisheries Research Division, Ministry of Agriculture \& Fisheries, Wellington, New Zealand

\begin{abstract}
Bimonthly samples of oysters Crassostrea gigas examined from June 1979 to June 1981, as part of a disease monitoring survey, showed the presence of several organisms within their mantle cavity, such as copepods, nematodes, ciliates and mudworms. A myicolid copepod and an alloeocoel turbellarian appear to be persistent and facultative invaders. A peculiar association is that of a chironomid insect larva which probably completes its developmental stages within the oyster. Histopathological examination reveals occasional swelling and disorganisation of the connective tissue and leucocyte infiltration around the oyster gut and the digestive diverticula, but these are considered to be histological anomalies, probably seasonal in character. The possible role of associated organisms in disease transmission and in contributing to stress is discussed.
\end{abstract}

\section{INTRODUCTION}

Outbreaks of disease and mass mortalities have affected oyster populations and their commercial production in many parts of the world. Measures against disease, however, have usually been crisis-responses to particular situations. As a consequence, many diseases, particularly epizootics, have not been clearly understood or analysed, nor is their aetiology fully known. As Sindermann (1979a) points out, 'examining mass mortalities while they are occurring can be an exciting but frustating experience, if no chronicle of events preceding the mortality is available'. A continuous surveillance of the environment and the parasites, predators and organisms associated with the oyster, together with a study of host responses, is required if a health profile of the oyster is to emerge. The continuity of observations, especially during periods when there is no appreciable mortality, may enable events and results to be recorded which could provide valuable data on the state of health of the oyster and of the factors affecting it (Sprague 1971, Sindermann 1979a).

It is likely that an oyster is under stress when abnormal conditions of salinity, temperature, nutrient availability or when environmental pollution exist (Sindermann 1979b), and particularly so after the spawning period. Under these conditions, parasites

(C) Inter-Research/Printed in F. R. Germany and associated organisms may increase in numbers and cause further stress.

In New Zealand, the industry focussing on the Pacific oyster Crassostrea gigas is still at an infant stage, producing $\$ 4$ to 5 million worth of oysters, mostly for export. No known cases of seasonal or sporadic mortality have occurred during the decade that the oyster has been actively farmed in the northern parts of the country. From 1979 onwards a continuous disease surveillance has also been in operation, during which detailed examination has been carried out on oysters of 12 to 18 mo age from an experimental site in the Bay of Islands in Northland. Also, with the commencement of farming operations, all cases of suspect, emaciated or dying oysters that have been reported by farmers have been investigated (own unpubl. data). The present paper provides details of the disease surveillance carried out over a period of 2 yr (1979 to 1981) as they particularly relate to associated organisms occurring within the body of the oyster, the conditions of shell and viscera and histopathological examination of major organs and tissues.

\section{MATERIALS AND METHODS}

Oysters collected as spat from 1978 onwards from the main commercial spat collecting site in the Mahurangi 
estuary $\left(36^{\circ} 30^{\prime} \mathrm{S} ; 174^{\circ} 45^{\prime}\right.$ E) were grown intertidally, at mean tide level, in Wairoa Bay, Bay of Islands $\left(35^{\circ} 15^{\prime} \mathrm{S}, 174^{\circ} 94^{\prime} \mathrm{E}\right)$. They were examined from time to time during studies on growth, condition and gonadal development until they were $1 \mathrm{yr}$ old. Oysters were then regularly sampled from June 1979 to June 1981, as far as possible every 2 mo, for disease surveillance when they were 1 to 2 yr old. Usually 50 oysters were taken at each sampling (but 30 in 1981) and cleaned of encrusting organisms and mud. Each oyster, after being dried on a paper towel, was measured (length, height, depth) and opened from the hinge end. The valves were held apart and the shell liquor from the mantle cavity was drained into a Petri dish. The right valve was then removed, and filtered seawater was squirted between the palps and gill lamellae and the mantle folds, and the wash allowed to drain into another dish. The oyster was then examined under a binocular stereo microscope and the condition of gill, mantle, palps and viscera noted, particularly features which varied from normal form and colour. The interior of the shell valves was examined after shucking the meat. An oblique cut was then made across the viscera from just below the level of the labial palps and a piece 5 to $7 \mathrm{~mm}$ thick removed and fixed in Davidson's fluid. The transverse section comprised planes through stomach, digestive diverticula, gut, connective tissue, both gill demibranchs, and mantle lobes. This was processed for histology in the usual way, and sections 5 to $7 \mu \mathrm{m}$ thick were cut and stained with eosin and haematoxylin. Histopathological examination was carried out in 15 to 20 oysters from each sample to determine whether there were any abnormal features, particularly in the digestive tubule epithelia, the Leydig connective tissue and the gill tissues. Any oyster which showed abnormal symptoms such as discolouration, lesions or emaciation was investigated in greater detail.

The mantle fluid and the wash from gills and palps was examined microscopically. Individual organisms found were mounted in filtered seawater on microscope slides, narcotised if necessary, and their sizes and characteristics noted while they were still alive, or were fixed and preserved for later examination and identification.

The live organisms were listed as nematodes, ciliates, copepods and so on, and no attempt was made initially to identify these any further. Later on, fixed and preserved specimens were re-examined and identified as far as possible up to the family level.

During histological examination, an assessment of seasonal gonadal development of each oyster was also made. A scoring system of 0 to 3 was adopted to show the degree of development: $0=$ immature or spent gonad; $_{1}=$ developing, and 2 = maturing follicles; $3=$ ripe or spawning gonad. The scores were summed and averaged for each sample to provide a general index of gonad development.

The climatological data relating to the period, recorded in the weather station directly above Wairoa Bay, is shown in Fig. 1 to provide background information. Mean sea surface temperatures in the Bay of Islands range between 15 and $23^{\circ} \mathrm{C}$, and salinity in the main basin is about $35 \%$ (Booth 1974), though after rain and floods, salinity has been observed to drop to 23 to $25 \%$ in the Wairoa Bay area (Dinamani unpubl.).

\section{RESULTS}

\section{Associated organisms}

The percentage occurrence of 7 commonly found groups of organisms associated with the oyster are given in Table 1. Also shown are incidences of shell damage (blisters, mudworm tunnels, other damage/ discolouration) and abnormalities of gill (scalloped or irregular margin, frayed or damaged lamellae, nodules, lesions).

The copepod Pseudomyicola spinosus and small

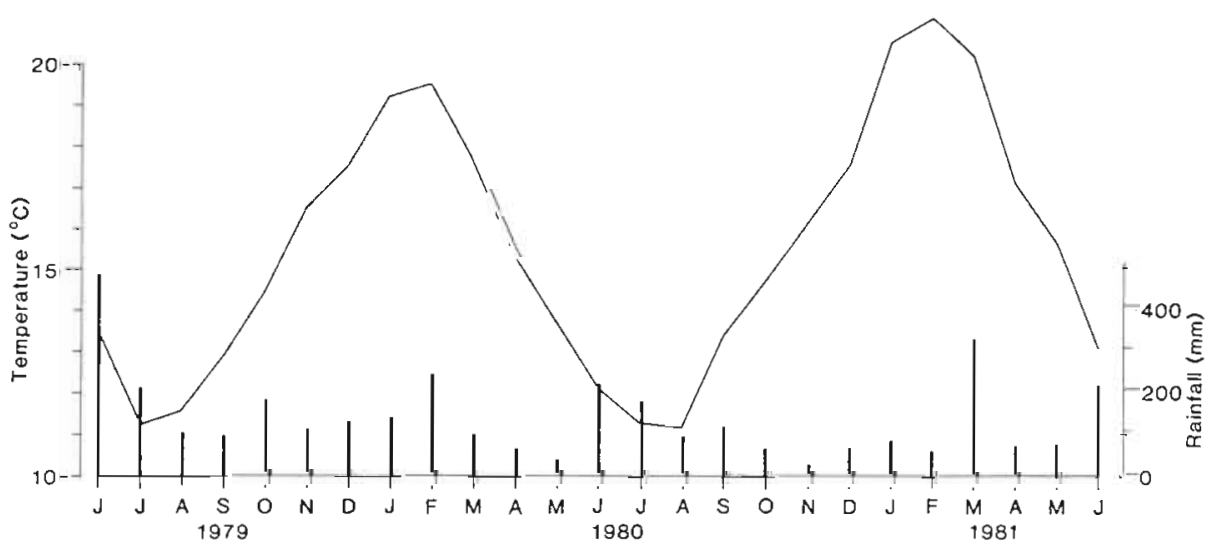

Fig. 1. Monthly mean air temperature and rainfall at Waitangi weather station, situated above Wairoa Bay (New Zealand), Jun 1979 to Jun 1981 
Table 1. Percent occurrences of 7 common associate organisms in farmed oysters Crassostrea gigass, examined from Jun 1979 to Jun 1981, together with percentages of shell and gill damage and gonad index of the sample

\begin{tabular}{|c|c|c|c|c|c|c|c|c|c|c|c|}
\hline $\begin{array}{l}\text { Time of } \\
\text { examination }\end{array}$ & n & $\begin{array}{l}\text { Pseudo- } \\
\text { myicola } \\
\text { spinous }\end{array}$ & Nematode & $\begin{array}{c}\text { Polydora } \\
\text { sp. }\end{array}$ & Ciliates & $\begin{array}{l}\text { Turbel- } \\
\text { larian }\end{array}$ & $\begin{array}{l}\text { Pinnotherid } \\
\text { crab }\end{array}$ & $\begin{array}{l}\text { Dipteran } \\
\text { larvae }\end{array}$ & $\begin{array}{c}\text { Shell } \\
\text { blisters } \\
\text { etc. }\end{array}$ & $\begin{array}{c}\text { Gill } \\
\text { injury }\end{array}$ & $\begin{array}{l}\text { Gonad } \\
\text { index }\end{array}$ \\
\hline \multicolumn{12}{|l|}{1979} \\
\hline Jun & 50 & 16 & 32 & 40 & 42 & 6 & 0 & 0 & 20 & 8 & 0 \\
\hline Aug & 50 & 54 & 64 & 22 & 60 & 0 & 10 & 0 & 4 & 14 & 1 \\
\hline $\mathrm{Oct}$ & 50 & 46 & 44 & 28 & 26 & 0 & 10 & 0 & 16 & 14 & 2 \\
\hline Dec & 50 & 36 & 16 & 30 & 16 & 24 & 16 & 8 & 16 & 4 & 3 \\
\hline \multicolumn{12}{|l|}{1980} \\
\hline Jan/Feb & 40 & 33 & 40 & 20 & 7 & 15 & 2 & 12 & 0 & 0 & 3 \\
\hline Mar & 50 & 20 & 28 & 18 & 8 & 8 & 2 & 14 & 14 & 2 & 0 \\
\hline Apr & 50 & 30 & 32 & 20 & 18 & 10 & 4 & 14 & 10 & 2 & 1 \\
\hline Jun & 50 & 36 & 66 & 12 & 24 & 12 & 4 & 26 & 20 & 6 & $0 / 1$ \\
\hline Aug & 45 & 33 & 26 & 4 & 13 & 27 & 6 & 4 & 4 & 2 & 1 \\
\hline Oct & 50 & 42 & 26 & 0 & 16 & 38 & 4 & 4 & 0 & 6 & $2 / 3$ \\
\hline Dec & 57 & 25 & 21 & 0 & 4 & 5 & 0 & 5 & 5 & 2 & 3 \\
\hline \multicolumn{12}{|l|}{1981} \\
\hline Feb & \multicolumn{11}{|c|}{ Regular sample not taken } \\
\hline Apr & 30 & 40 & 30 & 10 & 0 & 3 & 0 & 0 & 26 & 0 & 0 \\
\hline Jun & 30 & 20 & 33 & 6 & 0 & 0 & 0 & 0 & 17 & 16 & 0 \\
\hline
\end{tabular}

nematode worms are the most common organisms in the mantle cavity. Up to 7 nematodes and 11 copepods per oyster have been recorded in the mantle cavity; they are also seen in histological preparations of some oysters. The copepod commonly occurs within the folds of the labial palps, but has also been detected in stomach (Fig. 2), gut and within large ducts of the digestive diverticula. Largest specimens (ovigerous females) are nearly $2 \mathrm{~mm}$ long, but nauplii and copepodid stages have also been frequently recorded in the region of the palps and the anterior part of the gills. Copepods usually occur in over a third of the oysters examined, but higher numbers prevail in spring (Table 1).

Nematodes, probably larval forms, occur abundantly on the gill surfaces near the food grooves and within the mantle folds, in up to $66 \%$ of the oysters examined. The worms are usually small, measuring up to $1 \mathrm{~mm}$, tapered at both ends, with the highest prevalence in the winter months, although over $30 \%$ of oysters
Fig. 2. Copepod Pseudomyicola spinosus, found within the stomach of Crassostrea gigas $(\times 50)$

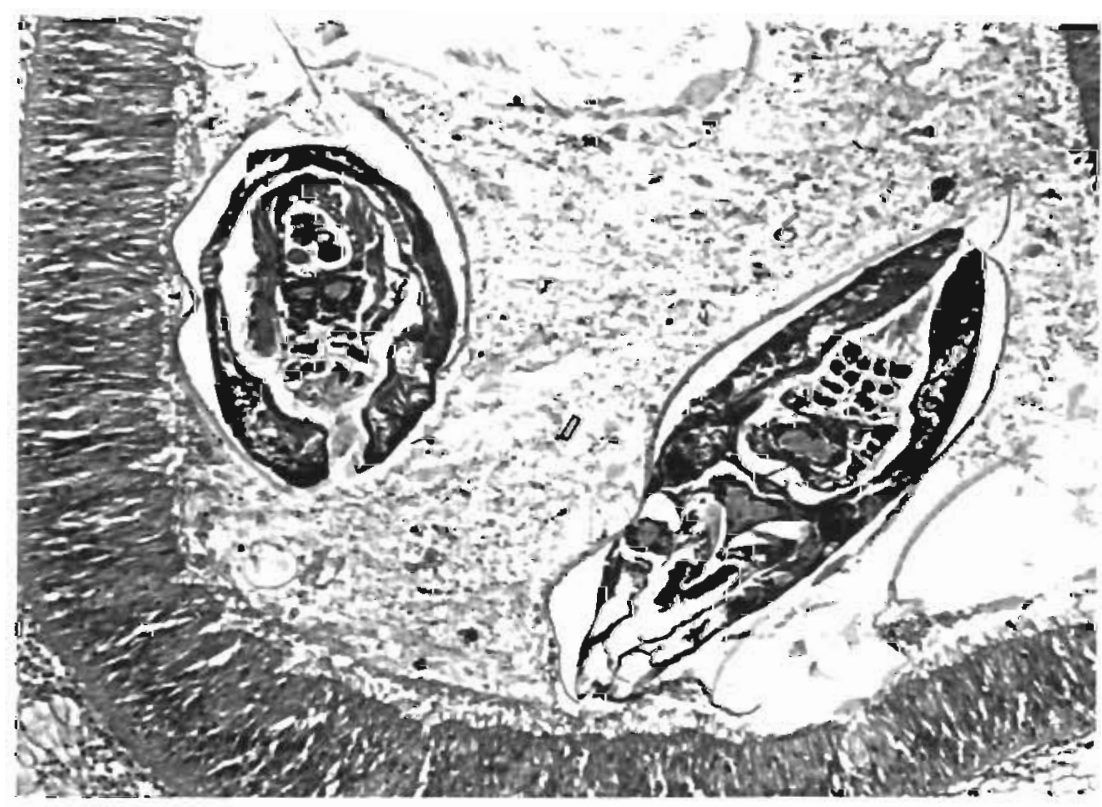


examined at any time of the year harbour these small worms. No attempt was made to identify the nematode fauna.

The next most common organisms recorded were the mud worm and ciliates. The mudworm Polydora sp. (websteri?) bores into the shell of the oyster and, in heavy cases of infestation, the mantle in contact with the worm trail is also discoloured. Oysters are usually affected near the anterior margin of the shell, particularly in the upper valve. Very large infestations have been recorded in older oysters (over 2 yr old; own unpubl. data) but during the present survey higher incidence was recorded during 1979/80 (Table 1). Ciliates identified as Thigmotrichida mostly inhabit gill surfaces and were generally very small (10 to 20 iin in diameter), oval or slightly pear shaped, and were most common in oysters examined in the winter and spring months. An unusually large ciliate $190 \mu \mathrm{m}$ long and $15 \mu \mathrm{m}$ wide), slightly green in colour, was found in a 2 yr old oyster in February 1981. The elongate body was dorsoventrally flattened, with a slight flexure towards the blunt end, with numerous rows of cilia. The ciliate was provisionally identified as a holotrichous thigmotrich, probably of the family Thigmophrya.

Turbellarians occurred in a small percentage of oysters in most months and were occasionally seen creeping over the gill with a looping motion. These were fairly small elongated worms (1. to $3 \mathrm{~mm}$ ), slender at one end but plump at the other, where the body was broadened and appeared to possess an adhesive area, though no sucker was seen. They have been provisionally placed in the Alloeocoela-Cumulata group, which includes examples of worms symbiotic on gills and mantle cavity of mytilids.
Pea crabs Pinnotheres novaezealandiae, normally single but occasionally as a pair, occurred in a small percentage of oysters. The crabs were occasionally found close to the labial palp, where they appeared to sit in a recess which becomes clearly outlined as a discoloured area covering the gills and the palps. The crabs varied in size from 4 to about $20 \mathrm{~mm}$, and occurred most commonly in spring.

A curious association was that of the larval stage of a chironomid insect found in the mantle cavity of the oyster. Larval chironomids were found invariably near the posterior side of the mantle/shell, close to the adductor muscle. Insect larvae were recorded regularly in a small percentage of the oysters, confirming their presence within the mantle cavity as a true association. Larvae were generally small, 4 to $8 \mathrm{~mm}$ long, greenish yellow, and only one was recorded per oyster on most occasions. A large larva with 2 exuviae was recorded in December 1980 and on one occasion 3 larvae of different sizes, probably representing instars, were found in the same oyster.

Occasionally pupal stages also occurred (Fig. 3) but no signs of larval tubes or insect eggs on the shell were found in any oyster. There were also no signs of injury to gill, mantle, palps or muscle. The highest incidence of the chironomid was recorded in June 1980 when $26 \%$ of the oysters examined had larvae inside them. The larvae and pupae have been provisionally identified by Dr. M. Winterbottom of Canterbury University as those of Clunio reinga (Leader) of the sub-family Orthocladiinae.

A wide variety of free-living organisms - such as bivalve larvae, ostracods, amphipods, cyprid stages, polychaete planktonic larva and nemertine worms have occasionally been found, often as single

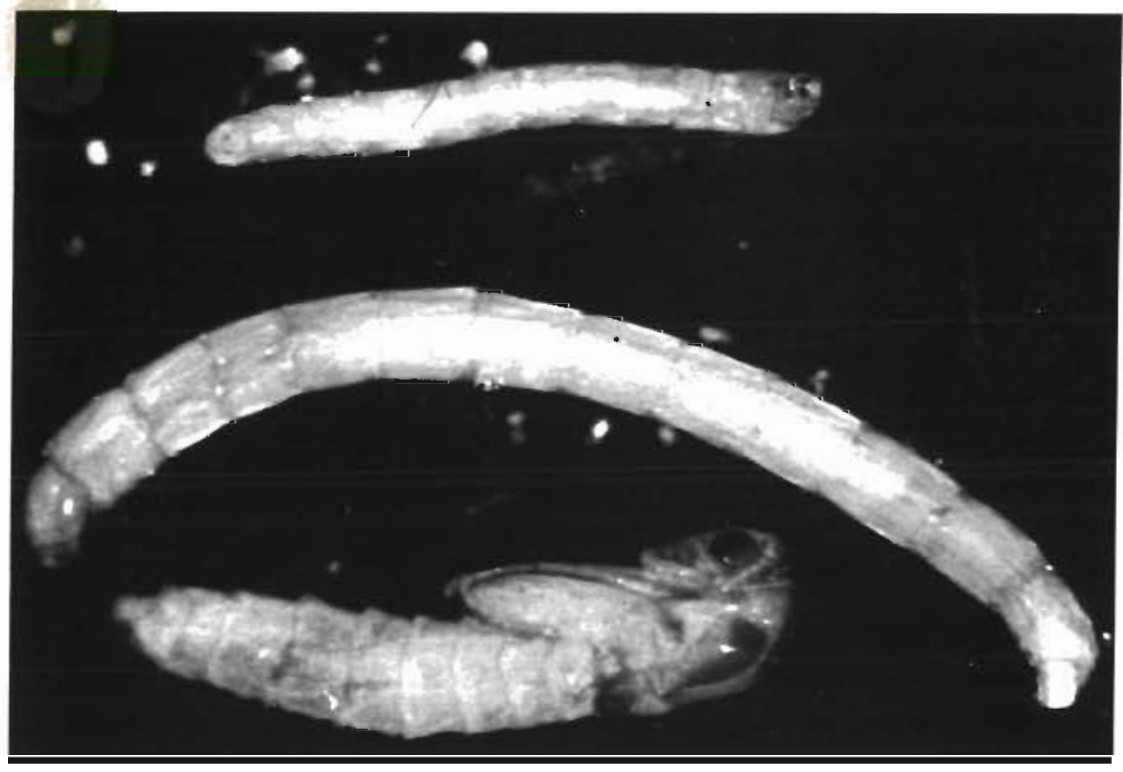

Fig. 3. Chironomid Clunio reinga (larvae and a pupa), found within the body of Crassostrea gigas. Largest larva is $8 \mathrm{~mm}$ long 
Fig. 4. Crassostrea gigas. Low magnification micrograph of section through digestive diverticula and gut to show leucocyte aggregations in this area $(\times 100)$

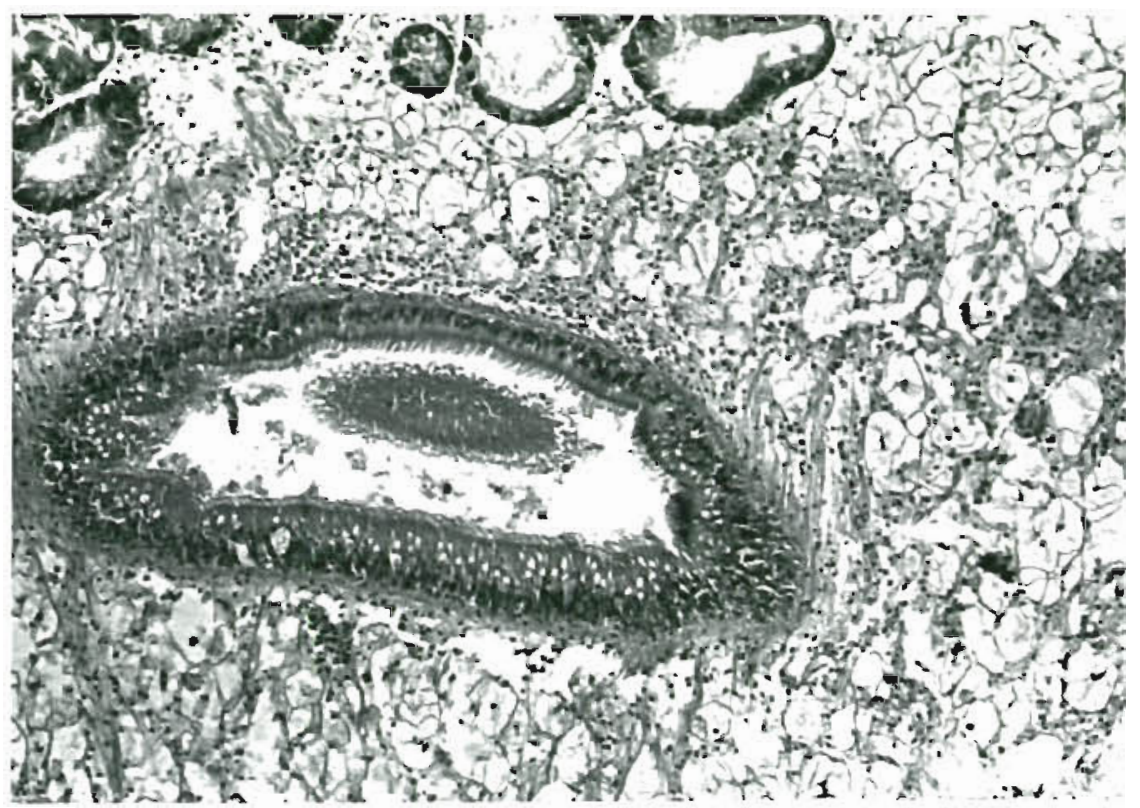

occurrences. These had apparently been entrapped by the oyster and were observed mostly in the mantle fluid.

\section{Histopathology}

Histopathological examination was carred out on 20 to $30 \%$ of oysters sampled, and particularly included individuals which appeared to be generally in poor condition. In general, leucocyte infiltration - particularly around gut and digestive tubules (Fig. 4) - was observed. Of the 220 oysters examined during the survey, a small percentage ( 8 to $10 \%$ ) of oysters from
January through Aprl 1980 and again February through Aprll 1981 were affected. This appeared to be a seasonal response, consequent on spawning and recovery. Small foc of sub-epithelial aggregations of haemocytes were detected in some oysters, and often both these conditions were accompanied by disorganisation of the connective tissue (Fig. 5) around the digestive organs.

A section of the tubules of the digestive diverticula in some oysters appeared empty, with squat epithelial lining and enlarged lumen. Atrophy of the tubule epithelium was encountered only once, in April 1980, when it showed extreme reduction and sloughed cell

Fig. 5. Crassostrea gigas. Low magnification micrograph of section through Leydig connective tissue, showing inflammation and disorganisation of normal structure $(\times 100)$

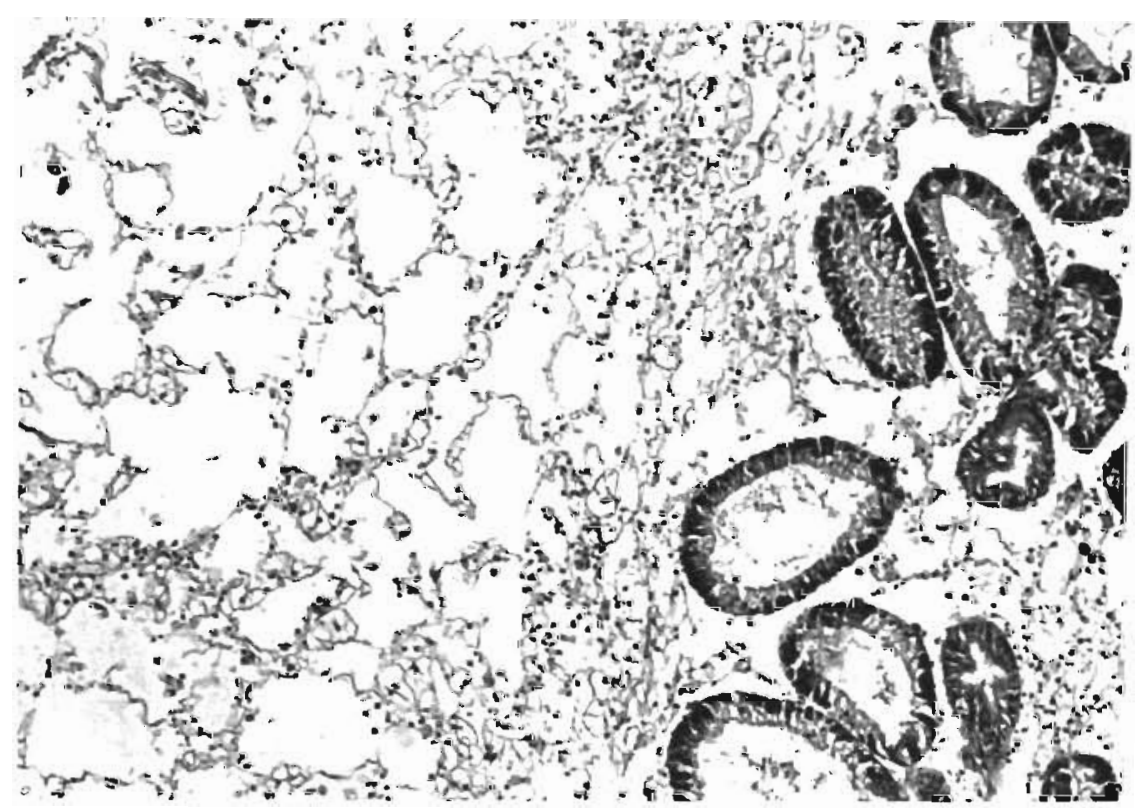


debris was found in the lumen (Fig. 6). The same specimen showed disorganised connective tissue around stomach and gut, and flattened epithelia on gill surfaces. The oyster itself was nearly transparent and harboured large numbers of ciliates.

Occasionally shell blisters cause greenish discolouration of the mantle, but histological examination of these areas has not revealed any lesion or hyperplasia. A greenish patch which occurred on the adductor muscle of 1 oyster in April 1981 and appeared to continue as a wedge into the muscle was examined in detail. The blotch appeared to be caused by a small blister on the right shell valve abutting against the muscle. Histological examination showed rupture and twisting of the muscle fibres, but no sign of any inflammation. The blister was probably caused by a boring organism (a gastropod?).

\section{DISCUSSION}

A variety of organisms are closely associated with Crassostrea gigas in Wairoa Bay and some of them are of a persistent and possibly seasonal nature. The main question remains then whether these organisms are transients in the mantle cavity of the oyster, or whether, once established, they represent a truly symbiotic assemblage, and whether some of them show facultative responses.

Organisms such as ciliates and nematodes are probably transients seeking shelter and avoiding desiccation or exposure during periods of low tide. However, the mantle cavity of the oyster does provide a suitable habitat (Cheng 1967) so that the advantages (food and shelter) conferred on the transient may lead to a more persistent association. Also, the presence of large numbers of oysters in close proximity - as is the case in a farm - offers an opportunity for rapid transmission of the organisms from one host to another and enables them to establish themselves in the area.

Pseudomyicolid copepods are symbiotic in the mantle cavity of a number of bivalves but in the oyster appear to complete their full life cycle within the mantle cavity: during this survey, nauplii, copepodid and adult stages of Pseudomyicola spinosus have been recorded in the same oyster, particularly during spring and summer. $P$. spinosus also invades the gut and is thus probably dependent in some way on the oyster (Dinamani \& Gordon 1974).

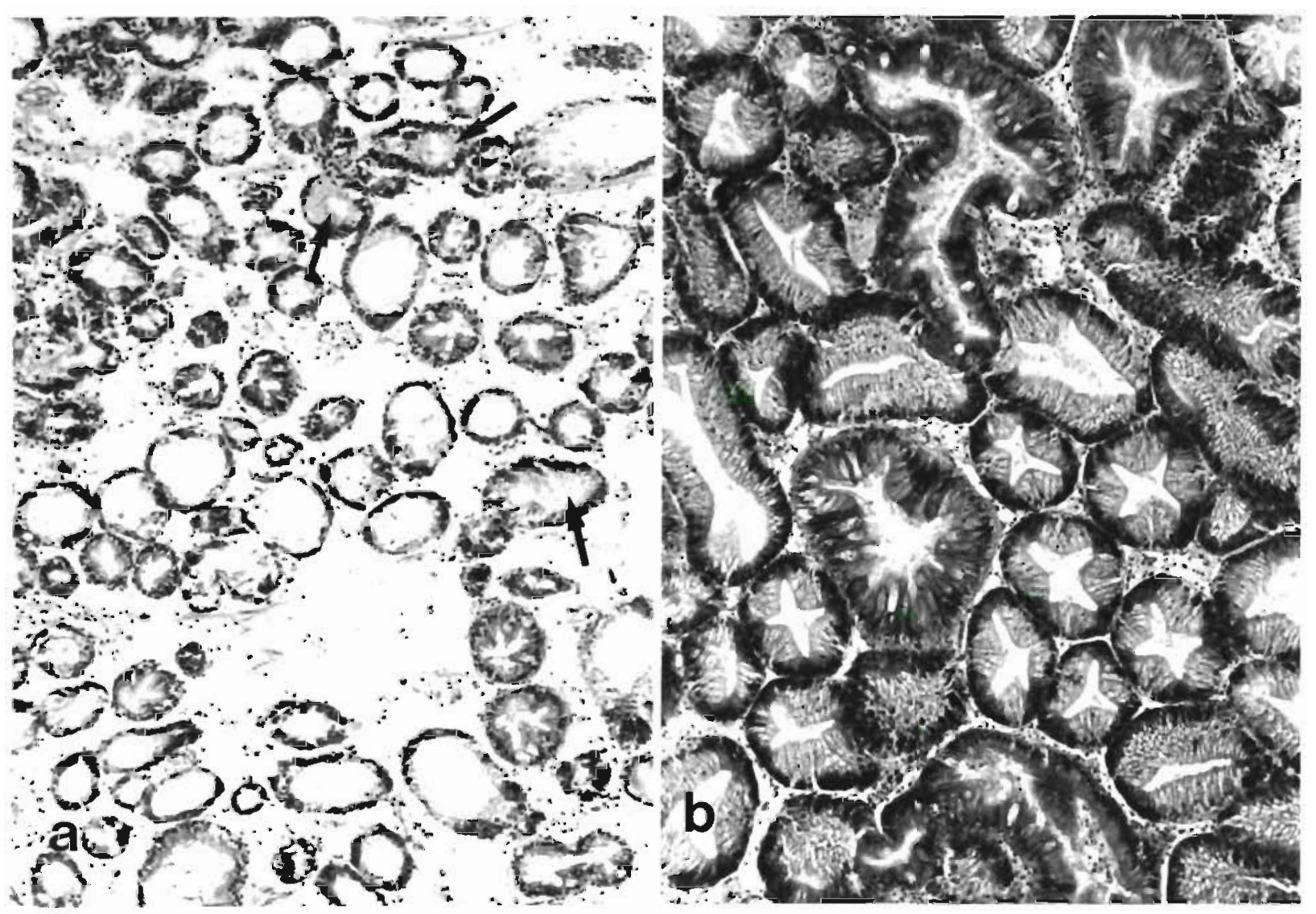

Fig. 6. Crassostrea gigas. (a) Abnormal tubules of digestive diverticula of an emaciated individual, showing extreme attenuation and atrophy of lining epithelia, occasionally sloughed material in the lumen (arrows). (b) Normal healthy tubules ( $\times 50$ ) 
The occurrence of the turbellarian adapted to live on the surface of gills of the oyster may be regarded as a facultative association. The alloeocoel Cumulata are found exclusively on gills of bivalves (Jennings 1971) and have an anterior adhesive disc, which may be of use in moving over the gill surface and in feeding on particles in mucus strings.

Aggregation of large numbers of oysters in localised areas seem to attract epibionts such as species of Polydora which use the oyster shell opportunistically as a substrate and occasionally affect the mantle. Whether, as a result, the worm actually causes injury or harm to the oyster is not clear: loss of condition (Galtsoff 1964), occasional damage to the adductor muscle (Loosanoff \& Engle 1943) and heavy mortalities (Roughley 1922) have all been reported as a result of mudworm infestation. Polydora websteri has been specifically pointed out by Korringa (1951) as causing injury to the European oyster. Observations made during the present survey on the incidence of shell damage (blisters, marginal breakages, discolouration of inner shell layer and mantle beneath) related to the degree of infestation by Polydora species does not show a close relation.

Some organisms, such as pinnotheriid crabs, are probably not transients in the mantle cavity of the oyster. They are reported to cause erosion in one or more gill demibranchs (Stauber 1945) and to cause mechanical injuries to the gill lamellae (Christensen \& McDermott 1958) in Crassostrea virginica. Jones (1975) also recorded discolouration and damage to the gills of Saccostrea glomerata, and a thickening of the mantle in areas where the crab had been 'parked' on the gill. Examples of this type of recesses, where the outline of the crab was clearly marked, were recorded during this survey, though no abnormality was observed in the overlying mantle tissue.

Some associations are difficult to explain: the presence of larval and pupal stages of a chironomid within the mantle cavity of the oyster is an example of an unusual association. Clunio marinus (sub-family Orthocladinae) is reported to occur in the mid-littoral zone in southern and western Britain, and their larvae have been recorded (Cranston 1982) 'associated with' oyster and mussel beds, but this is the first recorded occurrence of life stages of the insect within a marine bivalve. The presence of exuviae and pupal stages in the present survey may indicate that the chironomids complete their larval growth and metamorphosis within the oyster. Larvae and pupae of $C$. reinga though frequently recorded near the muscle/posterior mantle edge of Crassostrea gigas, apparently do not cause any damage to the tissues of the oyster. Observations on other chironomid associations with bivalves show that they often damage or cause injury to the host tissue. Gordon et al. (1978) reported on a parasitic association of the nearctic species Baeoctenus bicolor (larvae and pupae) with Anodonta cataracta. Larvae and pupae were found attached to the surface of the gills near the labial palps of the mussel, and the host showed large areas of gill damage. Larvae of Xenochironomus canterburyensis have been recorded between shell and mantle of Hyridella menziesi (Forsyth 1979), living as 'obligate inquilines'.

The presence of Clunio reinga larvae near the adductor muscle of the oyster raises doubt whether they cause any irritation to the muscle and affect valve closure. As Laird (1961) points out for bivalves subject to environmental stress, relaxation of the adductor muscle leads to the appearance within the oyster of many of the microorganisms from the surrounding area. Such irritation and relaxation of muscle, if prolonged, could result in interruptions of the oyster's normal feeding activity and make it more susceptible to invasion and infestation by other organisms.

Histopathological examination of the oyster is important because serious diseases are characterised histologically by excessive oedema, haemocyte proliferation within tissues and varying reduction in the height of the epithelial cells of the digestive tubules (Farley 1968). Some environmental factors, as pointed out by Quick (1971), can also result in a similar histological picture, but these features are not irreversible. Couch (1985) considered digestive diverticular atrophy and haemocyte proliferation as bioindicators of chemical pollutants in the environment. Even though haemocyte infiltration around the gut and at foci in the sub-epithelial connective tissue was detected during the present study, these did not show any relation to numbers or types of associated organisms present at the time. Thin emaciated oysters encountered on a few occasions in summer invariably showed reduction of some tubule epithelia, but as Meyers (1981) pointed out, it is possible that these probably indicate a physiological 'shut-down' of nonfunctioning tubules and may possibly reflect metabolic state and functional response to food availability. Complete atrophy of the tubules and sloughed material in the lumen was detected only once in the present study and occurred in an extremely emaciated oyster.

There are 2 other factors to be considered in associate-host relations: (a) whether some of the organisms are invaders entering the oyster at times of stress; (b) whether associated organisms may be implicated in disease. Apart from physical injury to gills and other organs of the host caused by organisms such as pinnotherids, do they play any other role? Mackin (1962) and Pauley et al. (1967) suggest that commensals - such as ciliates occurring in a healthy oyster may become a complicating factor in weakening the 
host as a secondary invader at times of stress. Other causes of stress such as pollutants, for example, have been shown to play a role in increased parasitism (Barszcz et al. 1978, Yevich \& Barszcz 1983). Leibovitz (1978) suggested that commensals like the pea-crab, that enter and leave the mantle cavity freely, may serve as intermediate hosts for gregarines (Nematopsis) whose spores infest shellfish. The recent finding by White et al. (1985) that Perkinsus marinus can be transmitted by the ectoparasitic snail Boonea impressa and effect oyster-to-oyster transfer, points to the potential for such mediation. In many oyster diseases and epizootics that cause mass mortalities, where life cycles and modes of infection of the parasite are mostly unknown, the possibility exists that other invertebrate organisms couid act as intermediate hosts or as reservoirs of spores (Balouet \& Poder 1985).

Oysters are physiologically under stress following spawning; organisms such as copepods, turbellarians and nematodes that occur in appreciable numbers at this time may subject the oysters to further stress. There is a need to quantify stress (by use of indicators such as heart-rate, pumping rate, filtration rate) and to understand the environmental and biological factors causing it. The percentage occurrence and seasonal prevalence of some of the associate organisms in this study indicate degree and extent of infestation of the oyster population and suggest the ease of transfer from host to host. The role of these organisms in disease transmission therefore warrants further study.

Acknowledgement. Mr Lindsay Allan provided valuable technical assistance during preparation, examination and processing of the oysters.

\section{LITERATURE CITED}

Balouet, G., Poder, M. (1985). Current status of parasitic and neoplastic diseases of shellfish - a review, In: Ellis, A. E. (ed.) Fish and shellfish pathology. Academic Press, London, p. 371-380

Barszcz, C. A., Yevich, P. P., Brown, L. R., Yarborough, J. D., Minchen, C. D. (1978). Chronic effects of three crude oils on oysters suspended in estuarine ponds. J. environ. Pathol. \& Toxicol. 1: 879-895

Booth, J. D. (1974). Observations on the hydrology of Bay of Islands, New Zealand. N.Z. Jl mar. Freshwat. Res. 8 671-689

Cheng, T. C. (1967). Marine molluscs as hosts for symbioses, with a review of known parasites of commercially important species. In: Russell, F. S. (ed.) Advances in marine biology, Vol. 5. Academic Press, London, p. 1-424

Christensen, A. M., McDermott, J. J. (1958). Life history and biology of the oyster crab, Pinnotheres ostreum Say. Biol Bull. mar. biol. Lab., Woods Hole 114: 145-179

Couch, J. A. (1985). Prospective study of infectious and non- infectious diseases in oysters and fishes in three Gulf of Mexico estuaries. Dis. aquat. Org. 1: 59-82

Cranston, P. S. (1982). A key to the larvae of the British Orthocladiinae (Chironomidae). Freshwater Biological Association, UK, Scientif. Publ. 45: 1-142

Dinamani, P., Gordon, D. B. (1974). On the habits and nature of the association of the copepod, Pseudomyicola spinosus, with the rock oyster, Crassostrea glomerata, in New Zealand. J. Invertebr. Pathol. 24: 305-310

Farley, C. A. (1968) Minchinia nelsoni (Haplosporida) disease syndrome in the American oyster, Crassostrea virginica. J. Protozool. 15: 585-599

Forsyth, D. J. (1979). Life stages and taxonomic affinities of Xenochironomus canterburyensis (Chironomidae, Diptera). N.Z. Jl Zool. 6: 467-472

Galtsoff, P. S. (1964). The American oyster Crassostrea virginica Gmelin. Fish. Bull. U.S. 64: 1-479

Gordon, M. J., Swan, B. K., Patterson, C. G. (1978). Baeoctenus bicolor (Diptera, Chironomidae) parasitic in Unionid bivalve molluscs, and notes on other ChironomidBivalve associations. J. Fish. Res. Bd Can. 35: 154-157

Jennings, J. B. (1971). Parasitism and commensalism in the Turbellaria. In: Advances in parasitology, Vol. 9. Academic Press, London, p. 1-32

Jones, J. B. (1975). Studies on animals closely associated with some New Zealand shellfish. Ph.D. thesis, Victoria University of Wellington, New Zealand

Korringa, P. (1951). The shell of Ostrea edulis as a habitat. Archs néerl. Zool. 10: 32-152

Laird, M. (1961). Microecological factors in oyster epizootics. Can. J. Zool. 39: 449-485

Leibovitz, L. (1978). Shellfish diseases. Mar. Fish. Rev. 40 (3): 61-64

Loosanoff, V. L., Engle, J. B. (1943). Polydora in oysters suspended in the water. Biol. Bull. mar. biol. Lab., Woods Hole 85: 69-78

Mackin, J. G. (1962). Oyster disease caused by Dermocystidium marinum and other microorganisms in Louisiana. Publ. Inst. mar. Sci. Univ. Tex. 7: 132-229

Meyers, T. R. (1981). Endemic diseases of cultured shellfish of Long Island, New York: adult and juvenile American oysters (Crassostrea virginica) and hard clams (Mercenaria mercenaria). Aquaculture 22: 305-330

Pauley, G. B., Chew, K. K., Sparks, A. K. (1967). Experimental infection of oysters (Crassostrea gigas) with thigmotrichid ciliates. J. Invertebr. Pathol. 9 (2): 230-234

Quick, J. A. (1971) (ed.). A preliminary investigation: the effect of elevated temperature on the American oyster, Crassostrea virginica (Gmelin). Florida Dept. of Natural Resources, Marine Research Lab. Prof. Pap. Ser. No. 15: $1-190$

Roughley, T. C. (1922). Oyster culture in the Georges River. Tech. Ed. Ser. (Technological Museum, Sydney) No. 25: $1-69$

Sindermann, C. J. (1979a). Oyster mortalities and their control. In: Pillay, T. V. R., Dill, M. A. (ed.) Advances in aquaculture, FAO Technical Conference on Aquaculture, Kyoto, Japan, 1976. Fishing News Books Ltd, London, p. $349-360$

Sindermann, C. J. (1979b). Pollution associated diseases of marine fish and shellfish: a review. Fish. Bull, U.S. 76 (4): $717-749$

Sprague, V. (1971). Diseases of oysters. A. Rev. Microbiol. 25: 211-230

Stauber, L. A. (1945). Pinnotheres ostreum, parasitic on the American oyster, Ostrea (Gryphaea) virginica. Biol. Bull. mar. biol. Lab., Woods Hole 88: 269--291 
White, M. E., Powell, E. N., Ray, S. M., Wilson, W. A. (1985). Perkinsus (Dermocystidium) marinus transfer and infestation by an ectoparasitic gastropod (Boonea impressa), with comments on the changes observed in the growth and biochemical composition of parasitised oysters. Nat. Shellfish. Ass., Norfolk, Va., 77th Ann. Mtg (Abstracts), p. 29
Yevich, P. P., Barszcz, C. A. (1983). Histopathology as a monitor for marine pollution. Results of the histopathologic examination of animals collected for the U.S. 1976 Mussel Watch programme. Rapp. P.-v. Réun. Cons. int. Explor. Mer 182: 96-102

Responsible Subject Editor: Dr. G. Lauckner; accepted for printing on October 22, 1986 